\title{
Evaluation of results of social rehabilitation programs for young people with behavioural problems
}

\author{
Martins Moors ${ }^{1,2}$ and Juris Osis ${ }^{2}$ \\ ${ }^{1}$ Rīga Stradinsš University, Social Work Department, Riga, Latvia \\ ${ }^{2}$ Riga City Council Welfare Department, Riga, Latvia
}

\begin{abstract}
New targeted social service - social rehabilitation program for young people with behavioural problems is implemented in Riga since 2016. The program beneficiaries are young people from social risk families with multiple social problems - learning difficulties, delinquency, low communication skills, difficulties in problem and conflict resolution, addictions, social isolation, etc. The program is provided by two organizations - "The Samaritan Association of Latvia" and the "Social Services Agency". The duration of the programs is 6 months and 8 months respectively, each Program provides services for 15 young people aged 13 to 18 years. The study analyses results of the Program implemented by the "Social Service Agency" for 15 young people. The main objective was to determine if the implementation of the Program improves the social functioning of young people having behavioural problems.
\end{abstract}

Key words: social rehabilitation, teenage youth, behavioural problems, negative social consequences.

\section{Introduction}

One of the problems that are becoming more and more common nowadays is the behavioural disorder of teenage youth, which leads to different kinds of negative social consequences. There are many early school leavers. Several studies [1-3] indicate that lack of motivation for learning and problems in the family (lack of parental participation in youth life) are key factors in early school leaving.

\subsection{Topicality of the problem}

According to the data of the Central Statistical Bureau of Latvia (CSB), in Latvia in three quarters of 2017, the average proportion of NEET youth in the total number of young people (NEET level) aged 15-24 was $11.0 \%$ (12.0\% in 2014), in the age group 25-29-15.8\% (19.9\% in 2014). Teachers point out that more and more of younger children are being overaggressive or child-insensitive, which is a no less dangerous trend. ${ }^{1}$

According to the reports of the State Children's Rights Protection Inspectorate on the work of Orphan's Courts in 2015-2017 [4], the number of families in which the child's

\footnotetext{
${ }^{1}$ Arvien jaunākiem bērniem novēro agresivitāti un uzvedības traucējumus: https://www.lsm.lv/raksts/ dzive--stils/veseliba/arvien-jaunakiem-berniem-novero-agresivitati-uzvedibastraucejumus.a242676/
}

(C) The Authors, published by EDP Sciences. This is an Open Access article distributed under the terms of the Creative Commons Attribution License 4.0 (http://creativecommons.org/licenses/by/4.0/). 
development and upbringing is not adequately ensured and for which the Orphan's Court has informed the municipal social service or other responsible institution during the reporting year, remains more than 1,500 annually. Moreover, in 2017 this was an increasing trend. The number of children in these families is approaching 3,000 each year.

The number of families with children in which there have been identified problems of social functioning in Riga has remained high during the last three years, i.e. in 2015, 2016, 2017 , the number of families receiving social work services has remained at the previous year's level.

In 2017, the social work service was provided to 3084 families with total family members of 12 405, of which 5151 were children. Social workers of the Riga Social Service have identified and worked also with child behaviour problems (roaming, begging, etc.). According to the data of Riga Crisis Centres, more and more teenagers with serious behavioural problems are coming to Riga crisis centres in recent years.

Also, providers of Support Program for foster families, guardians and adoptive parents [5], in 2012-2015 have found that a large proportion of adolescent from foster families who have participated in the program are experiencing behavioural problems, school nonattendance and communication problems with authorities. Adolescents have experienced these problems for a longer time.

\subsection{Characteristics of the problem and target group}

Observations and experiences from teachers and social workers show that behavioural disorders can most often be observed in students in 5-9 grade. However, when they already appear as school non-attendance and other externally visible manifestations, the first signs have usually been three to four years earlier. The first signs appear as indifference, apathy when the child cannot be "moved" either by positive or negative reinforcements. Specialists point out that behavioural disorders appear as non-social behaviour - tiny thefts, school conflicts with adults, small hooliganism, fights in school and on the street, nonfulfilment of requirements and disrespect for authority. Often young people due to the behaviour mentioned above have taken notice of the police. The use of addictive substances, as well as dependence on smart devices, is also observed. Behavioural disorders also include roaming and periodic overnight stay out of the home, staying outside usual living area.

Young people have defensive mechanisms such as aggression, non-compliance, challenging action, gross abuse, which is a protective position because, in reality, the teenager is unhappy. Children with auto-aggression and pseudo-suicidal behaviour are more common than before [6] - hand and foot scratching, suicidal talk that professionals need to see as a "red" warning. Specialists point out that this is more common in girls.

The paradigm of internal and external forces is trying to explain why people sometimes act strange and unpredictable. The basic assumption in this paradigm is that there are forces that occur both in the person and in the environment, and that are the cause of certain types of behaviour. It is important to note that such forces exist and act upon a person, creating certain behaviour. Most often, the external forces put pressure on the young person who has internal forces that are usually weak [7].

Therefore, the causes of behavioural problems can be found not only in the young person, but also in his/her social environment and, first and foremost, in the family and the school environment, which do not meet the specific needs of the young person.

The reasons for the social environment are such as the parents' long-lasting conflicts in relationships, such as divorce, or parental violence when the child is forced to defend the mother. Then the child reflects this conflict outside - in school, on the street. Often there is 
only one parent, usually a mother, so the daily regime is not respected, and the discipline that is usually associated with the male role in the family is missing. But there is often no quality relationship with at least one parent. This means that in a lifetime when the family should help to meet the three main development tasks of the young person- develop autonomy, resolve parent-adolescent conflict, and ensure parent-adolescent attachment [6], the parents and the family do not provide that.

Other causes in the social environment mentioned by social workers are the use of alcohol by parents, which leads them to not be a resource for young people. Also overcrowding, inadequate living conditions when young people do not have their "place", sometimes also authoritarian, too strict parents. Then, when children reach the age of adolescence, they protest in different forms. In these circumstances, children, parents and employees of institutions often lack the skills to deal with conflict situations.

The more difficult the family situation is, the earlier the child must make decisions that are irrelevant to their age - to lie, to defend and not to "betray" parents, to manipulate "helping" adults and so on. Because of the above-mentioned situations, young people cannot follow learning material, and this leads to a lack of interest in learning. Children who have grown up in their class age (left for another year) are ashamed to learn with younger children. Without the support of adults, young people themselves have no internal capacity to change this situation. Children develop low self-esteem, insecurity and isolation - they don't tell their feelings to anyone and nobody knows about them. Depression and depressive symptoms are observed - children do not want anything, show grief, grief gets externally, in clothing. In theoretical literature it is acknowledged that mental health problems are most common among adolescents, youth who have been abused, youth whose caregivers have poor parenting skills. Maltreated children often have difficulties with self-regulation and social-emotional processing that may contribute to the development of mental health problems [8].

Some of the youngsters have attachment disorders. They do not trust the relationship because they are so-called "spotted" children, for example, having brought by their grandmother in the countryside (without formally prescribed custody) and alternately with both parents.

Around the age of eight to nine, there is a fracture point when children get into a mental crisis because they realize that parents' words do not match with their actions, that parents lie. But for about thirteen years you can notice the indifference when you offer what you want, the child does not accept it. Therefore, at this age, if the above-mentioned serious behavioural disorders are observed, long time and a special program are needed to change the behavioural pattern of the young person.

From the foregoing, it can be concluded that the most common serious behavioural disorder among young people starts to appear in adolescence, typically characterized as a period of time between about 10-12 years of age and about 21-22 years of age. Particularly important during this period is peer recognition and acceptance [6]. During this time, the focus is transferred from parents to peers and short-term intense emotional relationships with friends. If a young person has behavioural and attachment disorders, the conflict between his pursuit of autonomy and the lack of mature psychological competences increases. This leads to unrealistic ambitions, even though interest in learning is completely disappearing [9].

\subsection{Characteristics of the social program}

To address the above issues new targeted social service - social rehabilitation program for young people with behavioural problems (hereinafter - the Program) is implemented in Riga since 2016. The Program beneficiaries are young people from social risk families 
with multiple social problems - learning difficulties, delinquency, low communication skills, difficulties in problem and conflict resolution, addictions, social isolation, etc. The Program is provided by two organizations - "The Samaritan Association of Latvia" and the "Social Services Agency". The duration of the programs is 6 months and 8 months respectively, each Program provides services for 15 young people aged 13 to 18 years. The study analyzes the results of the Program, implemented by the "Social Service Agency" for 15 young people.

It is recognized that developmentally appropriate treatment for adolescents are often most concerned with forming and maintaining peer relationships. Their emotion regulatory deficits may be most salient in peer contexts, and thus building social competence with peers should be a priority [8]. That is why the new program was group based.

\subsection{Theoretical perspective of the program}

The service is based on Resilience's psychological intervention, the community's creative approach and adventure pedagogy. The resilience of people denotes their ability not only to overcome difficulties, but also to gain new strength after the stressful experience. Resilience is the personality ability and vitality that helps to cope with the trauma and the understanding that this power exists in every person.

Resilience is "a positive adaptation in extreme conditions after a trauma that develops the individual's functional and cognitive abilities" [10-12].

The focal of resilience is the concept that people's abilities, their capacity to cope, are greater than believed, and the task is to help people mobilize their resources to cope with the problem. It is possible to train and develop these abilities to deal with difficulties. There are protective factors in one's life and that can help explain why one young person may cope better with adverse life events than another. Some young people are more intrinsically resilient than others because of a whole range of these protective factors [13]. This approach recognises that although it may not always be possible to protect young people from further adversity and that while it may not always be possible to provide an ideal environment for them, boosting their resilience should enhance the likelihood of a better long-term outcome. A resilience-based approach focuses on maximising the likelihood of a better outcome for young people by building a protective network around them. The concept of resilience increasingly offers an alternative framework for intervention, the focus being on the assessment of potential areas of strength within the young person's whole system. This approach enables a move away from an assumption that a parent or alternative placement will provide all that the young person needs. Instead the emphasis is on building a network of support from the resources available and adding to them with professional support where necessary. It also emphasises the importance of building on the potential areas of resilience within the young person by maximising opportunities for engaging in hobbies, associating with friends, experiencing success, contributing and so on [13].

By providing help, the focus is not on the problem but on the human resources and strengths. Resilience allows perceiving and treating a person who has suffered from a trauma or a serious living condition, as a personality, as a human being, not a victim. Consequently, resilience is based on the strengthening of resources, emphasizing of positive aspects, and personality acceptance, separating the personality from behaviour.

The Community's creative approach is geared toward teenagers' social and behavioural changes. Development of creative community involves not only helping professionals (social workers, psychologists, psychotherapists, educators) but also representatives of other professions from the community (working in a team) - artists, coaches, architects, cultural workers, musicians, managers, etc. Working in a united team, the emphasis is on education 
and building new experiences. The Community's creative approach is process-oriented and resource finding-oriented. Tasks for this approach are:

- Helping the target group to decide, plan, act and identify their own needs,

- Develop and mobilize individual and environmental / community resources,

- Develop a creative and innovative approach by acting more efficiently and interactively,

- Build closer links between service providers and target groups,

- To change conditions and environmental conditions to create new quality needs.

There is an assumption in the Community's creative approach - any experience is a lesson. Each lesson is personal and unique to everyone. The dynamics of experience form a process of change that promotes personality openness, critical thinking, the need to acquire new knowledge and skills, and encourages a change of attitude towards life.

Adventure Pedagogy is about gaining experience by living outside your usual environment or travelling and participating in various exciting activities. Adventure therapy has a positive effect on the self-confidence and self-esteem of the participants. It promotes mutual trust and responsibility, develops socially acceptable behaviour and teaches to seek help.

All these theoretical concepts were integrated in the new service - social rehabilitation program for young people with behavioural problems (hereinafter - the Program).

\subsection{Content of the social program}

Aim of the program is to promote the social integration of adolescents/young people at risk of social exclusion in Riga and to reduce the risks of social exclusion by providing social rehabilitation and support programs for social risk persons aged 13-18 years.

The program is holistic in composition and includes physical training, games and recreation, career development, relationship development, nutrition, relaxation training, and a social network analysis where each youth contracts with a "village" of adult supportive mentors.

During the implementation of the program, six themes are updated, which correspond to the main components of resilience:

1. Identity (self-esteem, personal goals, values - the aim is to strengthen authenticity, specific resources, look for ways the group can help strengthen each participant).

2. A sense of belonging, relationships with peers, parents (family goals, goals and initiatives of the group).

3. Structure and consistency (self-discipline, rights and obligations, responsibility).

4. Challenges (personal, group and family difficulties, overcoming them, risks and mitigating them).

5. Security and Support (awareness of external resources, experience to use them) - the aim is to learn the skills to ask and provide support.

6. Realistic optimism (future goals are hopeful and optimistic, but they are based on the reality of the current situation).

These six themes, or sections of the program, take the form of activities such as:

- Group relationship building camp (3 days),

- Creative group activities (Interactive communication/resilience psychology; nonviolence philosophy/survival skills; contemporary dance/freedom of movement; creative self-expression/music/drama/cinema/art) (256 hours-128 lessons/2 hours),

- Psychotherapy sessions (240 sessions/16 for adolescence and support person),

- Social worker counselling (300/20 for adolescence and support person), 
- Specialist consultations (narcologist, gynaecologist, career counsellor, specialist teacher, etc.) as needed (75 counselling/5 adolescents),

- Mentoring (600 hours/40 mentor hours per 1 teenager), Inter-institutional cooperation (regular inter-institutional meetings during the provision of the service) 120 hours per program $/ 8$ on average for adolescents,

- Lessons for adolescents with parents 96 hours/32 lessons $\times 3$ hours.

All program activities focus on changes in thinking, behaviour and attitudes, focus on things that succeed and regular positive feedback (building self-confidence), creating new and positive experiences for young people, development of awareness of actions and consequences. Program activities are regular and intense.

\section{Material and methods}

The main objective of the research was to determine if the implementation of the program improves the social functioning of young people with behavioural problems in Riga municipality.

An analysis was conducted on the grounds of the self-assessment of young people involved in the implementation of the program and their parents, in accordance with the 360-degree Competence assessment method adapted by the service provider.

The self-assessment of young people involved in the implementation of the program and their parents was conducted before and after participation in the program using the self-assessment questionnaire. According to the 360-degree Competence assessment method adapted by the service provider, self-assessment questionnaire comprised 20 questions, which were organized into four categories each with corresponding indicators: Motivation (6 indicators - School attendance, Diligence, Motivation, Reflection of the initiative, Vision of career, Persistence of interests), Emotional stability (7 indicators - Emotional balance, Skills to deal with conflict situations, Responsibility for actions, Ability to provide support, Ability to express constructive criticism, Respect for adults, Tolerance for peers), Social skills (4 indicators - Personal hygiene and self-care, Ability to follow the rules, Behavior, Ability to work in team) and Self-image (3 indicators - Self-esteem, Self-criticism, Creative selfexpression). Each of 20 questions asked to assess the level of each indicator on the scale from 0 (the lowest assessment level) to 10 (the highest assessment level).

Descriptive statistics were used to calculate the mean values for data processing. The non-parametric Wilcoxon signed rank test for two dependent samples was used to determine service efficiency. The size of the effect was calculated using the formula:

$$
r=z / \sqrt{N}
$$

where $r$ is the size of the effect, $z$ is the calculated value of the Wilcoxon signed rank test, and $N$ is the total number of participants from both samples. In statistics, the size of the effect is a quantitative indicator of the magnitude of the phenomena. Effect sizes complement the testing of statistical hypotheses and play an important role in Power analysis, sample size planning and meta-analysis. In order to determine how successful the implementation of the service will be in Riga municipality, Power analysis was used.

\section{Results}

The Wilcoxon signed rank test showedthat by the self-assessment of participants of the program all criteria of assessment have positive improvement (see Table 1). Assessment of 
Table 1. Mean values of assessment before and after the program.

\begin{tabular}{|l|c|c|c|c|}
\hline & \multicolumn{2}{|c|}{ Parents } & \multicolumn{2}{c|}{ Youngsters } \\
\hline & Before & After & Before & After \\
\hline Behavior & 5 & 7 & 5 & 7 \\
\hline Diligence & 4.5 & 7 & 3.5 & 5.5 \\
\hline School attendance & 5 & 7 & 5 & 8 \\
\hline Personal hygiene and self-care & 4.5 & 7.5 & 6.5 & 8 \\
\hline Responsibility for actions & 3.5 & 6 & 6.5 & 8.5 \\
\hline Motivation & 4.5 & 6.5 & 5.5 & 8 \\
\hline Self-esteem & 4.5 & 6.5 & 5.5 & 8 \\
\hline Emotional balance & 2 & 6 & 6 & 7.5 \\
\hline Ability to work in team & 5 & 6 & 5 & 7 \\
\hline Skills to deal with conflict situations & 4.5 & 6.5 & 6 & 8.5 \\
\hline Reflection of the initiative & 5 & 7 & 5 & 7 \\
\hline Self-criticism & 4 & 5.5 & 5 & 6 \\
\hline Ability to express constructive criticism & 4 & 7 & 5.5 & 7 \\
\hline Ability to provide support & 5.5 & 6.5 & 5 & 8 \\
\hline Respect for adults & 5 & 6.5 & 5.5 & 8.5 \\
\hline Tolerance for peers & 4 & 7 & 5.5 & 8 \\
\hline Vision of career & 3 & 6 & 4.5 & 6.5 \\
\hline Persistence of interests & 5.5 & 6 & 5 & 7.5 \\
\hline Ability to follow the rules & 2.5 & 4.5 & 4 & 6.5 \\
\hline Creative self-expression & 5.5 & 6.5 & 4.5 & 6.5 \\
\hline Total & 4.5 & 6.5 & 5 & 7.5 \\
\hline
\end{tabular}

parents showed positive improvement as well except for two criteria: School attendance and Ability to provide support. For example, in the criteria Ability to provide support parents did not see improvement, whereas, children found that they had the best results in this criterion.

The most remarkable improvements were recorded for following criteria: Personal hygiene and self-care, Emotional balance, Ability to express constructive criticism, Tolerance for peers, Vision of career, School attendance, Ability to provide support, Respect for adults.

The lowest improvements in assessment were observed for such indicators as Self-esteem, Self-criticism, Creative self-expression, which all 3 are indicators comprising Self-image category of indicators.

In general, parents evaluate the social functioning of their children more critical than the children themselves do. Statistically significant differences between parents and youngsters assessment were observed for such indicators as Responsibility for actions, Motivation, Emotional balance, Skills to deal with conflict situations, Respect for adults, and Ability to follow the rules - the self-assessment of youngsters for all 6 mentioned indicators was significantly higher than assessment given by the parents.

At the same time statistical analysis did not showed any differences in the selfassessment by the gender so it can be concluded that the program works equally efficiently for both boys and girls. On average, participants' social functioning improved by 2 
2.5 units. The calculated size of the program effect is $r=0.5$ (average) - this means that the program not only statistically but also practically significantly affect the youngsters' social functioning.

When performing Power analysis, it was found that with the existing sample we can only be $75 \%$ sure that the program will work at the same level of effectiveness if introduced in the whole Riga municipality. The minimum level of confidence for this study should be $80 \%$, and $95 \%$ is recommended. At present, data suggests that in order to be $95 \%$ sure that program will be effective if implemented in Riga, the experimental group should be increased to at least 27 children.

\section{Conclusions}

1. It was found that the implementation of the social rehabilitation program for young people with behavioural problems improves the social functioning of young people with behavioural problems from social risk families with multiple social problems in Riga municipality.

2. 360-degree Competence assessment method and tool proved to be effective approach for self-assessment of young people involved in the implementation of the program and their parents as it can give general assessment of the program as the whole as well as be more specific regarding various dimensions of the changes of the young person's behaviour.

3. Overall assessment of the program shows positive improvement in youngsters' social functioning. On average, social functioning of young people has improved by $2-2.5$ units. The service effect is $r=0.5$ (average) - it means that the service not only statistically but also practically substantially affects the social functioning of young people.

4. Youngsters' self-assessment and parents' assessment does not significantly differ in the majority of indicators of social functioning, but parents are more critical of the social functioning of their children than children themselves. Especially critical parents are for two criteria: School attendance and Ability to provide support- indicators the youngsters themselves estimate they have the best results. This difference in assessment is an important indicator for social workers when planning future case work with the family as a system.

5. There are no significant differences in the evaluation between girls and boys which means that program works equally well for both genders.

6. The greatest improvements are in the category "Emotional Stability": Emotional balance increased by 4 units, Ability to provide support, Ability to express constructive criticism, Respect for adults and Tolerance for peers increased by 3 units. The lowest improvements are in the category "Self-image", which include: self-esteem, selfcriticism and creative self-expression.

7. It can be concluded that the activities of the program give the most significant contribution to the social skills related to the provision of peer support, the ability to interact with other adults and peers. In turn, the smallest impact of program activities is on the psychological state of the young person, which suggests that this factor should be given more attention to in the future implementation of the program.

8. In turn, to argue that such result would also be achieved by the introduction of a service throughout the municipality of Riga, it is necessary to collect additional data with at least one group of youth - in other words the experimental group 
should be increased at least up to 27 participants to obtain $95 \%$ level of confidence of results.

9. Results of the assessment of the program prove that the combination of resilience's psychological intervention, the community's creative approach and adventure pedagogy is the successful foundation of the social rehabilitation program for young people with behavioural problems.

\section{References}

[1] Izglītības un zinātnes ministrija, Pêtījums par priekšlaicīgas mācību pamešanas iemesliem un riskiem jauniešiem vecuma grupā no 13 līdz 18 gadiem [Ministry of Education and Science. Study on causes and risks of early school leaving of youth aged 13 to 18] (2014). Available at: www.izm.gov.lv/images/statistika/ petijumi/41.pdf

[2] Maslo I., Jaunu izaicinājumu un to risināšanas iespēju identificēšana un analīze, kas ietekmē pieaugušo (18-24 gadi) iesaistǐšanos (atgriešanos) mūžamācǐšanās procesā [Identification and analysis of new challenges and opportunities influencing involvement (return) of adults (18-24 years) in lifelong learning] (2015). Available at: http://sf.viaa.gov.lv/library/files/original/Informativais_ zinojums_p_t_jumu_kops.pdf

[3] Izglītības un zinātnes ministrija, Pētījums par politikas alternatīvu veidošanu priekšlaicīgas mācību pārtraukšanas problēmas risināšanai [Ministry of Education and Science. Study on development of policy alternatives for tackling early school leaving (2015). Available at: http://www.izm.gov.lv/images/statistika/ petijumi/IZM_PMP_Gala_zinojums_AptaujuAptauj_ExcoloLatvia_2015.pdf

[4] Valsts bērnu tiesību aizsardzības inspekcija, Pārskati par bāriņtiesu darbu 20152017, gadā [The State Inspectorate For Protection Of Children's Rights. Reports on Orphan's Court Work years 2015-2017]. Available at: http://www.bti.gov.lv/ lat/barintiesas/statistika/

[5] Rīgas domes Labklājības departaments, Rīgas domes Labklājības departamenta gadagrāmata "Sociālā sistēma un veselības aprūpe 2017. gadā" [Riga City Council Welfare Department. Riga City Council Welfare Department Yearbook "Social System and Health Care in 2017"] (2018), 55-56. lpp Available at: http://www.ld.riga.lv/files/Gadagramatas/SOCIALA_SISTEMA_UN_ VESELIBAS_APRUPE_RIGA_2017_GADA.pdf

[6] J.B. Ashford, C.W. LeCroy, K.L. Lortie, Human Behavior in the Social Environment: A Multidimensional Perspective (Pacific Grove, CA: Brooks/Cole Pub. Co., 1997), p. 330, 333, 581

[7] R.A. Skidmore, G. Milton, O. Thackeray, O.W. Farley, L.L. Smith, S.W. Boyle, Introduction to social work (Boston, MA: Allyn and Bacon, 2000), 404

[8] Neuroscience for Social Work: Current Research and Practice, edited by Holly Matto, et al. (Springer Publishing Company, 2013), p. 112, 127

[9] Н.П. Рюгаард, Детиснарушениемпривязанности: указаниякоргани зачиитерапевтическойсредьдляребёнка: теория, причины, симптомы, лечение [Children with a violation of affection: instructions for organizing a therapeutic environment for a child: theory, causes, symptoms, treatment] (Keila: IgaleLapselePere, 2016), p. 312 
[10] M. Rutter, Implications of Resilience Concepts for Scientific Understanding, Ann. N.Y. Acad. Sci. 1094, 1-12 (2006) doi:10.1196/annals.1376.002

[11] N. Garmezy, Stress-Resistant Children: The Search for Protective Factors. In J.E. Stevenson (Ed.), Recent Research in Developmental Psychopathology: Book Suppl J. Child Psychol. Psychiatr. 4, 213-233 (1985)

[12] A.S. Masten, J. Coatsworth, The Development of Competence in Favorable and Unfavorable Environments: Lessons from Research on Successful Children. Am. Psychol. 53, 205-20 (1998)

[13] D. Brigid, S.Wassell, Adolescence: Assessing and Promoting Resilience in Vulnerable Children (Jessica Kingsley Publishers, 2002), p. 173 